\title{
Antioxidant and Hepatoprotective Activities of Hydroalcohol Extract of Homalium zeylanicum on Carbon tetrachloride Induced Liver Damage in Wistar Rats
}

\author{
Satish Kanhar ${ }^{1, *}$, Atish Kumar Sahoo', Ranjit Mohapatra² \\ 'Medicinal and Aromatic Plant Division, Regional Plant Resource Centre, Forest and Environment Department, Govt. of Odisha, Nayapalli, Bhubaneswar, Odisha, INDIA. \\ 2Department of Pharmaceutical Sciences, Utkal University, Bhubaneswar, Odisha, INDIA.
}

\begin{abstract}
Objectives: The ethyl acetate fraction of bark and leaf part of Homalium zelanicum showed potential antioxidant and hepatoprotective activities. So, this study is aimed to evaluate antioxidant and hepatoprotective activities of hydroalcohol extract of Homalium zelanicum in carbon tetrachloride induced hepatotoxicity. Methods: To evaluate antioxidant potential, in vitro antioxidant assays e.g. DPPH, superoxide, hydroxyl and nitric oxide and ex vivo antioxidant assay e.g. cell based antioxidant protection in erythrocytes (CAP-e) were performed. Hepatoprotective activities were evaluated by estimating biochemical parameters such as serum glutamate oxaloacetate transaminase (SGOT), serum glutamate pyruvate transaminase (SGPT), alkaline phosphatase (ALP), total bilirubin (TB) and total protein (TP). Hepatic markers such as thiobarbituric acid reactive species (TBARS), superoxide dismutase (SOD), catalase (CAT) and reduced glutathione (GSH) were evaluated. Results: Both bark and leaf of Homalium zeylanicum showed improvement in antioxidant protection of hepatocytes. As well as the extracts exhibited significant $(P<0.001)$
\end{abstract}

hepatoprotection against $\mathrm{CCl}_{4}$-induced liver injury. Conclusion: Among all the extracts, hydroalcohol extract of bark of Homalium zeylanicum (HZB, $400 \mathrm{mg} / \mathrm{kg}$ ) showed significant improvement in restoring serum and hepatic markers and the results were supported with histopathological observations.

Key words: Antioxidant, $\mathrm{CCl}_{4}$, Hepatic marker, CAP-e,

Homalium zeylaicum.

\section{Correspondence}

Mr. Satish Kanhar,

Phytotherapy Research Lab., Medicinal and Aromatic Plant Division, Regional Plant Resource Centre, Forest and Environment Department, Govt. of Odisha, Nayapalli, Bhubaneswar-751015, Odisha, INDIA.

Email id: satishkanhar4@gmail.com

DOI: 10.5530/jyp.2021.13.45

\section{INTRODUCTION}

Liver is a pivotal organ in human for metabolism and detoxification of xenobiotics, environmental pollutants, and chemotherapeutic agents and regulates cellular homeostasis. ${ }^{1}$ It is more susceptible to get damaged by various hepatotoxicants. In recent years, liver diseases greatly impact global health care system. The plant based drugs like Silybum marianum, Phyllanthus emblica, Picrorhiza kurroa etc. are widely and successfully used in the treatment of liver disorders. But still, there is need of less toxic and high efficacy plant based drugs. ${ }^{2-4}$

Homalium zeylanicum Benth. is predominantly found in evergreen forest and native to Eastern ghats of Andhra Pradesh of India. Previously, the plant was placed in the family Flacourtiaceae but in recent Angiosperm Phylogeny Group (APG)-IV system of classification, it is placed in Salicaceae. Traditional tribes of Rayalaseema region of Andhra Pradesh use leaves and bark of $H$. zeylanicum in the treatment of malaria, diabetes, rheumatism, wound healing, and inflammation..$^{5-7}$ In our previous studies, we have reported the presence of phenolics, flavonoids, steroids and terpenes in the species. ${ }^{8}$ Experimental evidences reflect antioxidant, anti-inflammatory, antidiabetic, hepatoprotective, antidyslipidemic, and anthelmintic properties. ${ }^{9-14}$ On basis of our earlier studies on hepatoprotective activities of ethyl acetate extract of $\mathrm{H}$. zeylanicum, we aimed to establish antioxidant and hepatoprotective effect of hydroalcohol extract of $H$. zeylanicum on carbon tetrachloride induced liver cirrhosis in wistar rats.

\section{MATERIALS AND METHODS}

\section{Chemicals, reagents and assay kits}

All chemicals, reagents and solvents were of analytical grade and purchased from HiMedia Laboratories Pvt. Ltd., India, Central Drug House (P) Ltd. India, and SISCO Research Laboratories Pvt. Ltd. (SRL), Mumbai, India. The standard drug silymarin was purchased from Cadila Pharma Ltd., India. Assay kits were purchased from HiMedia Laboratories Pvt. Ltd., and Tulip Group, Coral Clinical System, India.

\section{Plant material}

H. zeylanicum (bark and leaf) was collected from Tirumala hills, Chittoor district, Andhra Pradesh, India. The species were identified by Dr. K. Madhava Chetty, Taxonomist, Sri Venkateswara University, Tirupati, Andhra Pradesh, India. The voucher specimen was deposited in Regional Plant Resource Centre for future reference (7545/RPRC).

\section{Preparation of plant extract}

The bark and leaves of $H$. zeylanicum were shade dried. The plant material (each of $700 \mathrm{~g}$ ) was defatted with petroleum ether and then extracted with hydroalcohol $(70 \%)$ by hot maceration at $60-70^{\circ} \mathrm{C}$ for $72 \mathrm{~h}$. The extracts were dried to semisolid mass in a rotatory evaporator (R-100, Buchi, Switzerland). ${ }^{15}$ The percentage yields of hydroalcohol extract of bark and leaf of $H$. zeylanicum were recorded to be $16.14 \%$ w/w (HZB) and $14 \% \mathrm{w} / \mathrm{w}(\mathrm{HZL})$ respectively.

This is an open access article distributed under the terms of the Creative Commons Attribution-NonCommercial-ShareAlike 4.0 License, which allows others to remix, tweak, and build upon the work non-commercially, as long as the author is credited and the new creations are licensed under the identical terms. 


\section{In vitro antioxidant assays}

\section{2,2-diphenyl-1-picrylhydrazyl (DPPH) radical scavenging assay}

Serial diluted hydroalcohol extracts of $H$. zeylanicum (HZB and HZL, $50-200 \mu \mathrm{g} / \mathrm{ml}$ ) were mixed with DPPH solution (0.15\%). After five min incubation at room temp, absorbance of the reaction mixture was recorded at $515 \mathrm{~nm}$ by using microplate Reader (Bio-Tek Synergy H1MF, USA). ${ }^{13}$ Ascorbic acid was used as reference drug.

$$
\% \text { inhibition }=\left(A_{\text {control }}-A_{\text {sample }}\right) / A_{\text {control }} \times 100
$$

\section{Superoxide $(S O D)$ radical scavenging activity}

Hydroalcohol extracts of $H$. zeylanicum (HZB and HZL, 50-200 $\mu \mathrm{g} / \mathrm{ml}$ ) was mixed with NBT $(1 \mathrm{ml}, 156 \mu \mathrm{M})$, and NADH $(1 \mathrm{ml}, 468 \mu \mathrm{M})$. PMS $(100 \mu \mathrm{l}, 60 \mu \mathrm{M})$ was added to initiate the reaction and incubated at $25^{\circ} \mathrm{C}$ for $5 \mathrm{~min}$. Then, absorbance was read at $560 \mathrm{~nm}$ by using microplate Reader (Bio-Tek Synergy H1MF, USA). ${ }^{13}$ Quercetin was used as reference drug.

$$
\% \text { inhibition }=\left(A_{\text {control }}-A_{\text {sample }}\right) / A_{\text {control }} \times 100
$$

\section{Hydroxyl radical scavenging activity}

The reaction mixture was formed by hydroalcohol extracts of $H$. zeylanicum (HZB and HZL, 50-200 $\mu \mathrm{g} / \mathrm{ml}$ ), 2-deoxy-2-ribose (100 $\mu \mathrm{l}, 28 \mathrm{mM}$ ), ferric chloride $(200 \mu \mathrm{l}, 200 \mu \mathrm{M})$, EDTA $(1 \mathrm{mM})$, hydrogen peroxide $(100 \mu \mathrm{l}, 1 \mathrm{mM}))$, and ascorbic acid $(100 \mu \mathrm{l})$. After incubation of the reaction mixture at $37^{\circ} \mathrm{C}$ for $1 \mathrm{~h}$, each $1 \mathrm{ml}$ of TBA and TCA were added and heated at $100^{\circ} \mathrm{C}$ for $20 \mathrm{~min}$. the, the reaction mixture was allowed to cool to room temp and absorbance was recorded at $532 \mathrm{~nm}$ by using microplate Reader (Bio-Tek Synergy H1MF, USA). ${ }^{13}$ Ascorbic acid was used as reference drug.

$$
\% \text { inhibition }=\left(A_{\text {control }}-A_{\text {sample }}\right) / A_{\text {control }} \times 100
$$

Nitric oxide radical scavenging activity

Hydroalcohol extracts of H. zeylanicum (HZB and HZL, 50-200 $\mu \mathrm{g} / \mathrm{ml}$ ) was mixed with sodium nitroprusside $(10 \mathrm{mM})$ and incubated at $25^{\circ} \mathrm{C}$ for $1.5 \mathrm{~h}$. Then the reaction mixture was added to Griess reagent $(1 \mathrm{ml})$ and absorbance was recorded at $546 \mathrm{~nm}$ by using microplate Reader (Bio-Tek Synergy H1MF, USA). ${ }^{13}$ Quercetin was used as reference drug.

$$
\% \text { inhibition }=\left(A_{\text {control }}-A_{\text {sample }}\right) / A_{\text {control }} \times 100
$$

\section{Ex vivo antioxidant studies}

Cell based antioxidant protection in erythrocytes (CAP-e) assay

The sample solutions were prepared by dissolving HZB and HZL (each $0.5 \mathrm{~g})$ in normal saline $(0.9 \%, 5 \mathrm{ml})$ incubated on a rocker for $20 \mathrm{~min}$. Then, sample solution was centrifuged at $2400 \mathrm{r} / \mathrm{min}$ for $10 \mathrm{~min}$ and filtered. RBCs of albino rats $(0.1 \mathrm{ml})$ were treated with different dilutions of HZB and HZL. RBCs were treated with standard oxidising agent and considered as positive control and untreated RBCs were considered as negative control. The radical generator 2,2'-azobis-2-amidinopropane hydrochloride (AAPH) was added to initiate oxidative damage in cells and extent of damage was indicated by using $2,7^{\prime}$-dichlorofluorescein diacetate (DCF-DA). Fluorescence intensity of reaction mixture was measured by using microplate reader (Synergy H1M, BioTek, USA). Trolox was used as standard drug and $\mathrm{IC}_{50}$ of HZB and HZL were calculated $(\mathrm{mg} / \mathrm{ml}){ }^{14}$

$$
\text { Fluorescence Intensity }(F I)=\left(F I_{\max }-F I_{\text {sample }}\right) /\left(F I_{\text {sample }}-F I_{\text {untreated }}\right)
$$

\section{Experimental animals}

Swiss albino rats (120-150 g) of both sexes were purchased from Imgenex India Pvt. Ltd., Bhubaneswar, Odisha. All the rats were acclimatized for a week in standard laboratory conditions $\left(25-30^{\circ} \mathrm{C}\right.$ and $12 \mathrm{~h}$ light-dark cycle). Animals were fed with standard rat diet and water ad libitum. ${ }^{14}$ Experiments were conducted as specified guidelines of CPCSEA and approval of of Institutional Animal Ethical Committee (IAEC) of Regional Plant Resource Centre vide Regd. No. 1807/GO/R/S/15/CPCSEA.

\section{Acute toxicity study}

Acute toxicity of HZB and HZL were performed according to OECD guidelines. Swiss albino rats (150-200 g) of either sex were divided into 10 groups $(n=6)$. Animals were fasted overnight before the experiments. Animals were administered with five different doses (500, 1000, 2000, 3000 and $4000 \mathrm{mg} / \mathrm{kg}$ b.w.) of HZB and HZL and kept under observation for a period of $72 \mathrm{~h}$. The behavioral changes in sign and symptoms such as irritability, restlessness, fearfulness, touch response, gait, tremor, excess urination and defecation were observed. ${ }^{16,17}$

\section{Experimental design}

Animals of either sex were randomly divided into 7 groups $(n=6)$.

Group I (Normal control): Single daily dose of Tween 80 (1 ml/kg b. w. of distilled water) for 14 days.

Group II (Toxic control): Single daily dose of Tween $80(1 \mathrm{ml} / \mathrm{kg} \mathrm{b}$. w. in distilled water, p. o. $)+\mathrm{CCl}_{4} /$ olive oil $(1: 1 \mathrm{v} / \mathrm{v}, 1 \mathrm{ml} / \mathrm{kg}$ b. w., i. p. $)$ on every $72 \mathrm{~h}$ for 14 days.

Group III (Standard control): Single daily dose of silymarin $(0.7 \mathrm{ml} / \mathrm{kg}$ b. w.) $+\mathrm{CCl}_{4}$ /olive oil on every $72 \mathrm{~h}$ for 14 days

Group IV-V (HZB, low and high dose): Single daily dose of HZB 300 and $400 \mathrm{mg} / \mathrm{kg}$ b. W., respectively $+\mathrm{CCl}_{4} /$ olive oil on every $72 \mathrm{~h}$ for 14 days.

Group VI-VII (HZL, low and high dose): Single daily dose of HZL 300 and $400 \mathrm{mg} / \mathrm{kg}$ b. w., respectively $+\mathrm{CCl}_{4} /$ olive oil on every $72 \mathrm{~h}$ for 14 days

All the animals were anesthetized with diethyl ether after $24 \mathrm{~h}$ of the last treatment and sacrificed by cervical dislocation. Blood was collected by cardiac puncture and allowed to coagulate. After $30 \mathrm{~min}$, blood was centrifuged at $2500 \mathrm{r} / \mathrm{min}$ for $10 \mathrm{~min}$ at $4^{\circ} \mathrm{C}$ (5424 R, Eppendorf, Germany). Serum was collected and stored at $4^{\circ} \mathrm{C}$ for biochemical analysis. Liver was removed and rinsed with cold normal saline. Liver was dissected into two sections. One section was kept in formalin (10\%) for histopathological examination and other section was stored at $-86^{\circ} \mathrm{C}$ deep freezer (U410-86, Eppendorf, Germany) for analysis of hepatic markers. ${ }^{14,15}$

\section{Biochemical estimation of serum markers}

Biochemical estimation of serum markers such as serum glutamate oxaloacetate transaminase (SGOT), serum glutamate pyruvate transaminase (SGPT), alkaline phosphatase (ALP), total bilirubin (TB) and total protein (TP) were performed by following the standard protocols of diagnostics kits (Coral Clinical System, India).

\section{Biochemical estimation of hepatic markers Estimation of thiobarbituric acid reactive substance (TBARS)}

Thiobarbituric acid reactive substance was estimated by using assay kit. The blank, standard and sample solutions were prepared by mixing each of $100 \mu \mathrm{l}$ of water, MDA and liver homogenate to $2 \mathrm{ml}$ of colour development solution respectively. The reaction mixture was warmed for $1 \mathrm{~h}$ and then cooled for $10 \mathrm{~min}$. Then the mixture was centrifuged at $3000 \mathrm{r} / \mathrm{min}$ for $10 \mathrm{~min}$ at $4^{\circ} \mathrm{C}$ and absorbance was recorded at $540 \mathrm{~nm}$ by using multimode microplate reader (Synergy H1MF, BioTek, USA).

\section{Estimation of superoxide dismutase (SOD)}

Liver homogenate $(0.5 \mathrm{ml})$ was mixed with sodium carbonate $(1 \mathrm{ml}$, $50 \mathrm{mM})$, NBT $(0.4 \mathrm{ml}, 24 \mu \mathrm{M})$, EDTA $(0.2 \mathrm{ml}, 0.1 \mathrm{mM})$ and hydroxylamine hydrochloride $(0.4 \mathrm{~m}, 1 \mathrm{mM})$. Then, absorbance of the reaction 
mixture was read at $560 \mathrm{~nm}$ at every $30 \mathrm{~s}$ for 5 min by using multimode microplate reader (Synergy H1MF, BioTek, USA). ${ }^{18}$

\section{Estimation of catalase (CAT)}

The reaction mixture was prepared by mixing liver homogenate $(1 \mathrm{ml})$, $\mathrm{H}_{2} \mathrm{O}_{2}(1 \mathrm{ml}, 30 \mathrm{mM})$ and phosphate buffer $(1 \mathrm{ml}, 50 \mathrm{mM}$, pH 7.4). Then, absorbance of the reaction mixture was recorded at $240 \mathrm{~nm}$ by using by multimode microplate reader (Synergy H1MF, BioTek, USA). ${ }^{19}$

\section{Estimation of reduced glutathione (GSH)}

The reaction mixture was prepared by mixing liver homogenate $(0.01$ $\mathrm{ml}$ ), phosphate buffer ( $2 \mathrm{ml}, \mathrm{pH} 8.4$ ), 5,5'-dithiobis (2-nitrobenzoic acid) $(0.5 \mathrm{ml})$ and distilled $\mathrm{H}_{2} \mathrm{O}(0.4 \mathrm{ml})$. Then, absorbance was read at $412 \mathrm{~nm}$ within 15 min by using multimode microplate reader (Synergy H1MF, BioTek, USA). ${ }^{20}$

\section{Histopathological studies}

Liver tissues were embedded in paraffin and tissue sections $(5 \mu \mathrm{M})$ were prepared by using microtome (MRM-ST, Medimeas, India). Tissue sections were stained with haematoxylin-eosin ( $\mathrm{H} \& \mathrm{E}$ ) for the microscopic observations (Olympus BX51). ${ }^{14}$

\section{Statistical analysis}

All the experimental datas were expressed as mean \pm SEM. Statistical analysis was performed by using ANOVA followed by Tukey's multiple comparison tests using GraphPad Prism software (version 7.0, GraphPad, USA).

\section{RESULTS}

\section{In vitro antioxidant assays}

Antioxidant activities of hydroalcohol extracts of $H$. zeylanicum (HZB and HZL) were assessed by different in vitro antioxidant assays (DPPH, $\mathrm{SOD}, \mathrm{NO}$ and $\mathrm{OH}$ ) and the results were expressed as $\mathrm{IC}_{50}$. In DPPH assay, the $\mathrm{IC}_{50}$ value of HZB and HZL was found to be $62.51 \pm 0.28$ and $89.24 \pm 0.36 \mu \mathrm{g} / \mathrm{ml}$ respectively whereas $\mathrm{IC}_{50}$ value of standard drug ascorbic acid was $25.7 \pm 0.13 \mu \mathrm{g} / \mathrm{ml}$. In SOD radical scavenging assay, the $\mathrm{IC}_{50}$ value of HZB and HZL was found to be $76.44 \pm 0.15$ and 93.13 $\pm 0.21 \mu \mathrm{g} / \mathrm{ml}$ respectively whereas IC $_{50}$ value of standard drug quercetin was $28.44 \pm 0.26 \mu \mathrm{g} / \mathrm{ml}$. In hydroxyl radical scavenging assay, the $\mathrm{IC}_{50}$ value of HZB and HZL was found to be $87.69 \pm 0.33$ and $109.25 \pm 0.62$ $\mu \mathrm{g} / \mathrm{ml}$ respectively whereas $\mathrm{IC}_{50}$ value of standard drug ascorbic acid was $30.2 \pm 0.37 \mu \mathrm{g} / \mathrm{ml}$. In nitric oxide radical scavenging assay, the $\mathrm{IC}_{50}$ value of HZB and HZL was found to be $71.58 \pm 0.47$ and $98.73 \pm 0.66 \mu \mathrm{g} / \mathrm{ml}$ respectively whereas $\mathrm{IC}_{50}$ value of standard drug quercetin was $28.6 \pm 0.1$ $\mu \mathrm{g} / \mathrm{ml}$ (Table 1).

Table 1: In vitro antioxidant assays of hydroalcohol extract of leaf and bark of $H$. zeylanicum.

\begin{tabular}{cccc}
\hline Assays & HZB $(\mu \mathrm{g} / \mathrm{ml})$ & HZL $(\mu \mathrm{g} / \mathrm{ml})$ & Standard $(\mu \mathrm{g} / \mathrm{ml})$ \\
\hline DPPH & $62.51 \pm 0.28$ & $89.24 \pm 0.36$ & Ascorbic acid $(25.7 \pm 0.13)$ \\
SOD & $76.44 \pm 0.15$ & $93.13 \pm 0.21$ & Quercetin $(28.44 \pm 0.26)$ \\
OH & $87.69 \pm 0.33$ & $109.25 \pm 0.62$ & Ascorbic acid $(30.2 \pm 0.37)$ \\
NO & $71.58 \pm 0.47$ & $98.73 \pm 0.66$ & Quercetin $(28.6 \pm 0.1)$ \\
\hline
\end{tabular}

DPPH-2,2-diphenyl-1-picrylhydrazyl; SOD-superoxide; OH-hydroxyl; NO-nitric oxide; HZB-hydroalcohol extract of bark of H. zeylanicum; HZL-hydroalcohol extract of leaf of $H$. zeylanicum
Table 2: IC $\mathrm{C}_{50}$ values of hydroalochol extract of bark and leaf of H. zeylanicum (HZB and HZL) in CAP-e assay.

\begin{tabular}{cc}
\hline Plant part & $\mathbf{I C}_{50}(\mathrm{mg} / \mathrm{ml})$ \\
\hline HZB & 48.23 \\
HZEL & 71.46 \\
Standard drug (Trolox) & 40.75 \\
\hline
\end{tabular}

\section{Ex vivo antioxidant studies \\ Cell based antioxidant protection in erythrocytes (CAP-e) assay}

CAP-e assay of ethyl acetate extract of bark and leaf of H. zeylanicum (HZB and HZL) were performed. $\mathrm{IC}_{50}$ values of $\mathrm{HZB}$ and HZL were found to be 48.23 and $71.46 \mathrm{mg} / \mathrm{ml}$, respectively whereas the $\mathrm{IC}_{50}$ value of standard drug trolox was found to be $40.75 \mathrm{mg} / \mathrm{ml}$ (Table 2).

\section{Acute toxicity studies}

In acute toxicity studies of hydroalcohol extract of bark and leaf of H. zeylanicum, both HZB and HZL treated groups showed $50 \%$ death at dose of $4000 \mathrm{mg} / \mathrm{kg}$ b.w. so, $\mathrm{LD}_{50}$ was recorded as $4000 \mathrm{mg} / \mathrm{kg}$. Thus, effective dose were determined to be $400 \mathrm{mg} / \mathrm{kg}$ b.w. (high dose) and $300 \mathrm{mg} / \mathrm{kg}$ b.w. (low dose).

\section{Biochemical estimation of serum markers}

The administration of hepatotoxicant $\left(\mathrm{CCl}_{4}\right)$ caused liver damage and indicated by the level of serum markers e.g. SGOT, SGPT, ALP, TP and TB. The level of SGOT, SGPT, ALP and TB were significantly ( $\left.{ }^{c} p<0.001\right)$ elevated in the toxic control group (SGOT, 88.16 $\pm 1.27 \mathrm{U} / \mathrm{l}$; SGPT, 146.32 $\pm 1.16 \mathrm{U} / \mathrm{l}$; ALP, $190.62 \pm 0.9 \mathrm{U} / \mathrm{l}$; TB, $3.1 \pm 0.16 \mathrm{mg} / \mathrm{dl}$ ) as compared to normal group (SGOT, $41.33 \pm 0.19 \mathrm{U} / \mathrm{l}$; SGPT, $55.29 \pm 1.44 \mathrm{U} / \mathrm{l}$; ALP, $70.37 \pm 0.88 \mathrm{U} / \mathrm{l}$; TB, $0.98 \pm 0.04 \mathrm{mg} / \mathrm{dl})$. But, pretreatment of HZB (400 $\mathrm{mg} / \mathrm{kg})$ was significantly $\left({ }^{c} p<0.001\right)$ lowered the level of SGOT $(56.13 \pm$ $1.54 \mathrm{U} / \mathrm{l}), \operatorname{SGPT}(72.63 \pm 1.50 \mathrm{U} / \mathrm{l}), \operatorname{ALP}(97.51 \pm 0.98 \mathrm{U} / \mathrm{l})$, and TB $(1.43$ $\pm 0.01 \mathrm{mg} / \mathrm{dl}$ ) which were comparable to positive control group (SGOT, $49.77 \pm 1.13 \mathrm{U} / \mathrm{l} ; \mathrm{SGPT}, 63.48 \pm 1.23 \mathrm{U} / \mathrm{l}$; ALP, $77.48 \pm 1.22 \mathrm{U} / \mathrm{l}$; TB, $1.1 \pm$ $0.03 \mathrm{mg} / \mathrm{dl})$. In toxic control group, TP level was significantly ( $\left.{ }^{c} p<0.001\right)$ reduced $(2.16 \pm 0.49 \mathrm{mg} / \mathrm{dl})$ than the normal control group $(5.33 \pm 0.25$ $\mathrm{mg} / \mathrm{dl})$. But, HZB (400 $\mathrm{mg} / \mathrm{kg}$ ) treated groups exhibited significant $\left({ }^{a} p<0.05\right)$ increase in the level of total protein $(4.71 \pm 0.14 \mathrm{mg} / \mathrm{dl})$ in comparison to the positive control group $(4.89 \pm 0.31 \mathrm{mg} / \mathrm{dl})$ (Table 3$)$.

\section{Biochemical estimation of hepatic markers}

The level of MDA was estimated by TBARS assay kit. MDA level was significantly $\left({ }^{c} p<0.001\right)$ increased in toxic control group $(7.4 \pm 0.28 \mathrm{nM} / \mathrm{mg}$ protein) as compared to normal control group $(3.6 \pm 0.44 \mathrm{nM} / \mathrm{mg}$ protein). However, administration of HZB $(400 \mathrm{mg} / \mathrm{kg})$ was significantly $\left({ }^{c} p<0.001\right)$ reduced the MDA level $(4.5 \pm 0.36 \mathrm{nM} / \mathrm{mg}$ protein) and was comparable to positive control group $(3.89 \pm 0.12 \mathrm{nM} / \mathrm{mg}$ protein) (Table 4$)$. The level of SOD was found to be $7.98 \pm 0.35 \mathrm{U} / \mathrm{mg}$ protein in normal control group whereas $\mathrm{CCl}_{4}$ administration significantly $\left({ }^{c} p<0.001\right)$ depleted the level of SOD in toxic control group $(4.1 \pm 0.74 \mathrm{U} / \mathrm{mg}$ protein). The reduced level of SOD was significantly ( ${ }^{\mathrm{a}} p<0.05$ ) restored in HZB (400 $\mathrm{mg} / \mathrm{kg})$ treated group $(6.32 \pm 0.12 \mathrm{U} / \mathrm{mg}$ protein) and comparable to positive control group $(7.22 \pm 0.55 \mathrm{U} / \mathrm{mg}$ protein). Catalase enzyme activity was significantly ( $\left.{ }^{c} p<0.001\right)$ decreased in toxic control group $(20.76 \pm 1.19 \mathrm{U} / \mathrm{mg}$ protein) in comparison to normal control group $(40.51 \pm 1.32 \mathrm{U} / \mathrm{mg}$ protein). However, the administration of HZB $(400 \mathrm{mg} / \mathrm{kg})$ group showed significant $\left({ }^{\mathrm{a}} p<0.05\right)$ rise in the level of 
Table 3: Biochemical estimation of serum markers.

\begin{tabular}{cccccc}
\hline Groups & SGOT (U/l) & SGPT (U/I) & ALP (U/l) & TP (mg/dl) & TB (mg/dl) \\
\hline Normal control & $41.33 \pm 0.19$ & $55.29 \pm 1.44$ & $70.37 \pm 0.88$ & $5.33 \pm 0.25$ & $0.98 \pm 0.04$ \\
Toxic control & $88.16 \pm 1.27^{\mathrm{c}}$ & $146.32 \pm 1.16^{\mathrm{c}}$ & $190.62 \pm 0.9^{\mathrm{c}}$ & $2.16 \pm 0.49^{\mathrm{c}}$ & $3.1 \pm 0.16^{\mathrm{c}}$ \\
Positive control & $49.77 \pm 1.13^{\mathrm{c}}$ & $63.48 \pm 1.23^{\mathrm{c}}$ & $77.48 \pm 1.22^{\mathrm{c}}$ & $4.89 \pm 0.31^{\mathrm{c}}$ & $1.1 \pm 0.03^{\mathrm{c}}$ \\
HZB 300 & $58.36 \pm 1.46^{\mathrm{c}}$ & $79.50 \pm 1.70^{\mathrm{c}}$ & $113.08 \pm 1.45^{\mathrm{c}}$ & $3.57 \pm 0.18^{\mathrm{c}}$ & $1.64 \pm 0.01^{\mathrm{b}}$ \\
HZB 400 & $56.13 \pm 1.54^{\mathrm{c}}$ & $72.63 \pm 1.50^{\mathrm{b}}$ & $97.51 \pm 0.98^{\mathrm{c}}$ & $4.71 \pm 0.14^{\mathrm{a}}$ & $1.43 \pm 0.01^{\mathrm{a}}$ \\
HZL 300 & $71.24 \pm 1.59^{\mathrm{c}}$ & $93.42 \pm 1.67^{\mathrm{c}}$ & $139.08 \pm 0.96^{\mathrm{c}}$ & $4.4 \pm 0.17^{\mathrm{b}}$ & $1.77 \pm 0.04^{\mathrm{b}}$ \\
HZL 400 & $66.35 \pm 1.06^{\mathrm{c}}$ & $88.50 \pm 1.81^{\mathrm{c}}$ & $127.38 \pm 0.94^{\mathrm{c}}$ & $4.57 \pm 0.24^{\mathrm{b}}$ & $1.50 \pm 0.09^{\mathrm{b}}$ \\
\hline
\end{tabular}

Values are given in mean $\pm \operatorname{SEM}(n=6)$. Statistical significance differences were represented as ${ }^{a} p<0.05$, ${ }^{b} p<0.01$, and ${ }^{c} p<0.001$ in comparing the normal, negative, positive and test control groups as evaluated by one way ANOVA and Tukey's multiple range test.

SGPT-serum glutamate pyruvate transaminase, SGPT-serum glutamate oxaloacetate transaminase, ALP-alkaline phosphatase, TP-total protein, TB-total bilirubin, HZB-hydroalcohol extract of bark of $H$. zeylanicum, HZL-hydroalcohol extract of leaf of $\mathrm{H}$. zeylanicum

Table 4: Biochemical estimation of hepatic markers.

\begin{tabular}{ccccc}
\hline Groups & MDA (nM/mg protein) & SOD (U/mg protein) & CAT (U/mg protein) & GSH (nM/mg protein) \\
\hline Normal control & $3.6 \pm 0.44$ & $7.98 \pm 0.35$ & $40.51 \pm 1.32$ & $40.57 \pm 1.69$ \\
Toxic control & $7.4 \pm 0.28^{\mathrm{c}}$ & $4.1 \pm 0.74^{\mathrm{c}}$ & $20.76 \pm 1.19^{\mathrm{c}}$ & $23.7 \pm 1.34^{\mathrm{c}}$ \\
Positive control & $3.89 \pm 0.12^{\mathrm{c}}$ & $7.22 \pm 0.55^{\mathrm{c}}$ & $36.95 \pm 1.27^{\mathrm{c}}$ & $36.92 \pm 1.58^{\mathrm{b}}$ \\
HZB 300 & $5.33 \pm 0.02^{\mathrm{a}}$ & $5.16 \pm 0.02^{\mathrm{c}}$ & $27.57 \pm 1.62^{\mathrm{b}}$ & $28.69 \pm 1.22^{\mathrm{b}}$ \\
HZB 400 & $4.5 \pm 0.36^{\mathrm{c}}$ & $6.32 \pm 0.12^{\mathrm{a}}$ & $30.16 \pm 1.33^{\mathrm{a}}$ & $30.97 \pm 0.36^{\mathrm{a}}$ \\
HZL 300 & $5.11 \pm 0.36^{\mathrm{a}}$ & $6.23 \pm 0.22^{\mathrm{a}}$ & $25.31 \pm 1.58^{\mathrm{c}}$ & $29.54 \pm 1.14^{\mathrm{b}}$ \\
HZL 400 & $5.10 \pm 0.35^{\mathrm{ns}}$ & $6.14 \pm 0.28^{\mathrm{a}}$ & $28.32 \pm 1.33^{\mathrm{c}}$ & $29.63 \pm 1.50^{\mathrm{b}}$ \\
\hline
\end{tabular}

Values are given in mean $\pm \operatorname{SEM}(n=6)$. Statistical significance differences were represented as ${ }^{a} p<0.05,{ }^{b} p<0.01$, and ${ }^{c} p<0.001$ in comparing the normal, negative, positive and test control groups as evaluated by one way ANOVA and Tukey's multiple range test.

MDA-malondialdehyde, SOD-superoxide dismutase, CAT-catalase, GSH-reduced glutathione, HZB-hydroalcohol extract of bark of H. zeylanicum, HZL-hydroalcohol extract of leaf of $H$. zeylanicum.

catalase $(30.16 \pm 1.33 \mathrm{U} / \mathrm{mg}$ protein) and comparable to positive control group $(36.95 \pm 1.27 \mathrm{U} / \mathrm{mg}$ protein) (Table 4$)$. On $\mathrm{CCl}_{4}$ administration, the level of GSH was significantly $\left({ }^{c} p<0.001\right)$ reduced in toxic control group $(23.7 \pm 1.34 \mathrm{nM} / \mathrm{mg}$ protein $)$ in comparison to normal control group ( $40.57 \pm 1.69 \mathrm{nM} / \mathrm{mg}$ protein). However, the treatment of HZB $(400 \mathrm{mg} / \mathrm{kg})$ was significantly $\left({ }^{\mathrm{a}} p<0.05\right)$ elevated the GSH level $(30.97 \pm$ $0.36 \mathrm{nM} / \mathrm{mg}$ protein) and was comparable to toxic control group (36.92 $\pm 1.58 \mathrm{nM} / \mathrm{mg}$ protein) (Table 4 ).

\section{DISCUSSION}

In human body, free radicals are continuously generated in metabolism and pathological conditions. These radicals severely affect biological macromolecules and leads to degenerative diseases. To counteract free radicals endogenous antioxidants and antioxidant enzymes are present in our body system which may fail in case of excess increase in free radicals and oxidative stress. Till date, many synthetic drugs are available to treat but these have adverse side effects. In the present study, in vitro, ex vivo and in vivo antioxidant potential and hepatoprotection ability of hydroalcohol extract of bark and leaf of $H$. zeylanicum were evaluated.

DPPH assay is simple and rapid antioxidant assay to measure the radical scavenging potential of any substance. It is a stable free radical and has ability to accept electron or hydrogen atom to become stable reduced form of DPPH molecule. DPPH solution shows absorbance at $517 \mathrm{~nm}$ and appears as violet coloured solution and upon reduction it becomes colourless. From the disappearance of its colour, the antioxidant activity of substance can be measured. In the present study, HZB exhibited less
$\mathrm{IC}_{50}$ value $(62.51 \pm 0.28 \mu \mathrm{g} / \mathrm{ml})$ as compared to HZL which demonstrated better antioxidant activity of HZB. In normal physiological processes, superoxide radicals are generated in our body which directly or indirectly damage essential biomolecules by formation of hydrogen peroxide, peroxy radicals or peroxy nitrite radicals. Also, it is associated with initiation mechanism of lipid peroxidation. In the present study, superoxide radicals are generated by PMS-NADH system. HZB extract showed higher inhibitory action towards scavenging superoxide radicals and exhibited lower $\mathrm{IC}_{50}$ value $(76.44 \pm 0.15 \mu \mathrm{g} / \mathrm{ml})$ as compared to HZL. Hydroxyl radicals are highly reactive oxygen species that reacts with polyunsaturated fatty acids (PUFA), membrane proteins, DNA and other biomolecules. Also, it initiates lipid peroxidation in cells. In this study, HZB showed promising free radical scavenging activity inhibition towards hydroxyl radicals. As shown in Table 1, HZB possessed less $\mathrm{IC}_{50}$ value $(87.69 \pm 0.33$ $\mu \mathrm{g} / \mathrm{ml})$ than HZL which demonstrated its antioxidant potential. Nitric oxide is highly reactive free radical generated from L-arginine. It is produced in endothelial cell, and brain. Primarily it reacts with proteins and other free radicals such as superoxide radicals to form toxic peroxynitrite radicals. In in vitro experiment, it is produced from sodium nitroprusside and resulted in increase in the absorbance at $546 \mathrm{~nm}$. However, different concentrations of HZB reduced its absorbance and exhibited $\mathrm{IC}_{50}$ value of $71.58 \pm 0.47 \mu \mathrm{g} / \mathrm{ml}$. Thus it concluded that HZB possess strong antioxidant potential than HZL. Among both the extracts, HZB showed highest radical scavenging activity which may be attributed to the presence of phenolic and flavonoids that neutralize free radicals by donating hydrogen or electron to it. ${ }^{21-23}$ 
CAP-e assay was performed to evaluate antioxidant potential of the extracts in ex vivo (RBC) model. The oxidation of fluorescent indicator DCF-DA to DCF occurs in the presence of free radicals and developed green solution. However, the addition of HZB exhibited highest cellular antioxidant potential which was attributed to the presence of phenolic, flavonoids and other antioxidant principles which have ability to penetrate cell membrane of $\mathrm{RBC}$ and thus protected from oxidative damage. ${ }^{14}$ In experimental in vivo animal model, the administration of hepatotoxicant $\mathrm{CCl}_{4}$ induces hepatotoxicity by altering metabolic functions and also causes morphological change in hepatic cells. Hepatic cells consist of high concentration of SGOT, SGPT and ALP and due to damage in cell membrane, these enzymes leak into the blood and mark hepatic injury. Hepatoprotective effect of the extracts can be evaluated by the extent of decrease in the level of these enzymes in blood serum. Among all the extracts, HZB (400 mg/kg) was significantly lowered the level of SGOT, SGPT and ALP in $\mathrm{CCl}_{4}$ intoxicated rats and the results were comparable to positive control group. ${ }^{24-26}$ The administration of $\mathrm{CCl}_{4}$ caused disruption of polyribosome in endoplasmic reticulum and thus reduces biosynthesis of proteins. The level of total protein was significantly restored in HZB $(400 \mathrm{mg} / \mathrm{kg})$ treated groups than other groups. The results were found to be comparable to positive control group. ${ }^{27,28}$ Hepatotoxin induced liver injury cause alteration in the secretion of bile by the liver which resulted in increase in the level of TB in serum. But, oral administration of HZB (400 mg/kg) was significantly lowered the level of TB as compared to other extracts and the results were comparable to positive control group. ${ }^{29}$

$\mathrm{MDA}$ is an oxidative stress marker in hepatic injury. In $\mathrm{CCl}_{4}$-induced hepatotoxicity, the trichloromethyl or trichloroperoxy free radicals initiate lipid peroxidation and damage the cell membrane. In experimental rats, the administration of $\mathrm{CCl}_{4}$ caused increase in lipid peroxidation and the level of MDA increased in toxic control group. But, administration of HZB (400 mg/kg) showed significant reduction in MDA level towards normal than other groups. ${ }^{30}$ Superoxide radicals are produced in respiratory electron transport reaction. It reacts with nitrous oxide to form peroxynitrite and cause damage to biological molecules. It can be removed by SOD an antioxidant enzyme which helps in conversion of superoxide free radicals into hydrogen peroxide and molecular oxygen. Hydrogen peroxide, a reactive oxygen species produced as a result of superoxide formation and aerobic metabolism. It plays critical role in apoptosis, inflammation and immune cell activation. Catalase, an antioxidant enzyme involved detoxification of hydrogen peroxide and form oxygen and water. On exposure to hepatotoxicant, superoxide and hydroxyl radicals are generated in the cells and its level increase and inactivate antioxidative enzymes such as SOD and CAT. But, pretreatment of HZB (400 mg/kg) showed significant increase in the level of these enzymes than other groups and the results were comparable to positive control group. ${ }^{31}$ Glutathione is an oxidant present in cells. Intracellular GSH is responsible for detoxification of xenobiotics such as free radicals. Oxidative stress induced pathological conditions caused reduction in the level of $\mathrm{GSH}$. In the present study, $\mathrm{CCl}_{4}$-induced hepatic injury wass marked by decrease in the level of GSH in toxic control group as compared to normal control group. However, pretreatment of HZB (400 mg/kg) showed significant improvement in the level of GSH than other groups and the results were found to be similar to positive control group. ${ }^{31}$

The histopathological studies directly support the results of biochemical estimations of serum and hepatic markers. The groups pretreated with hydroalcohol extract of bark and leaf of $H$. zeylanicum showed significant improvement in hepatotoxicity as compared to the toxic control group. The histopathological results of HZB 400 group were found to be similar with standard drug treated groups (Figure 1).
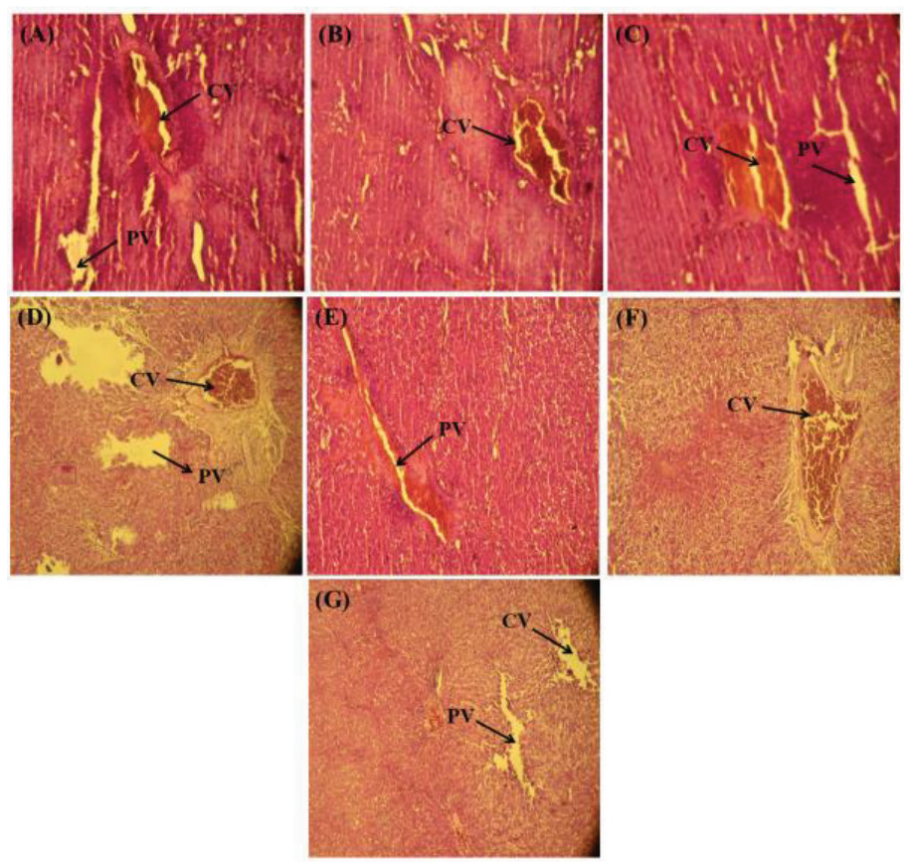

Figure 1: Photomicrographs of liver sections in experimental rats.

A: Normal group showed the presence of CV, PV and normal hepatocytes. $\mathrm{B}$ : Toxic $\left(\mathrm{CCl}_{4}\right)$ group revealed severe damage in normal cellular architecture and disappearance of PV and narrowed CV. C: Standard (silymarin) treated group showed significant recovery of hepatocytes, CV and PV. D and E: HZB-400 and HZB-300 treated group showed moderate recovery of hepatocytes, CV and PV. F and G: HZL-400 and HZL-300 treated group recovered with appearance of $C V, P V$ and hepatocytes.

CV-central vein, PV-portal vein

\section{CONCLUSION}

Hydroalcohol extract of bark and leaf of $H$. zeylanicum possess antioxidant and hepatoprotective activities. The possible bio-efficacy of the extract may be attributed to high content of antioxidants such as phenolic and flavonoids which are responsible for management of oxidative stress in liver cirrhosis. Also, histopathological studies also corroborate the activity of the extracts. Thus, the present study validates the usage of this plant in traditional medicine for treatment of liver disorder and further research is needed to establish bioactive molecules of this species.

\section{ACKNOWLEDGEMENT}

Financial support for this work was provided by the National Medicinal Plant Board (NMPB), Department of AYUSH, Govt. of India, New Delhi (Grant no. Z.18017/87/CSC/R\&D/OR-01/2013-14-NMPB/2292).

\section{CONFLICT OF INTEREST}

The authors declare no conflict of interest.

\section{ABBREVIATIONS}

Angiosperm: Phylogeny Group (APG); HZB: Bark of H. zeylanicum; HZL: Leaf of $H$. zeylanicum; DPPH: 2,2-diphenyl-1-picrylhydrazyl; SOD: Superoxide; CAP-e: Cell based antioxidant protection in erythrocytes; SGOT: Serum glutamate oxaloacetate transaminase; SGPT: Serum glutamate pyruvate transaminase; ALP: Alkaline phosphatase; TB: Total bilirubin; TP: Total protein; TBARS: Thiobarbituric acid reactive 
substance; SOD: Superoxide dismutase; CAT: Catalase; GSH: Reduced glutathione.

\section{REFERENCES}

1. Sathesh Kumar S, Ravi Kumar B, Krishna Mohan G. Hepatoprotective effect of Trichosanthes cucumerina Var cucumerina L. on carbon tetrachloride induced liver damage in rats. J Ethnopharmacol. 2009;123(2):347-50. doi: 10.1016/j. jep.2009.02.023, PMID 19429383.

2. Luper S. A review of plants used in the treatment of liver disease: part 1. Altern Med Rev. 1998;3(6):410-21. PMID 9855566.

3. Gulati RK, Agarwal S, Agrawal SS. Hepatoprotective studies on Phyllanthus emblica Linn. and quercetin. Indian J Exp Biol. 1995;33(4):261-8. PMID 7558182

4. Chander R, Kapoor NK, Dhawan BN. Effect of picroliv on glutathione metabolism in liver and brain of Mastomys natalensis infected with Plasmodium berghei Indian J Exp Biol. 1992;30(8):711-4. PMID 1459651.

5. Sandhya S, Sai KP, Vinod KR, David BK. Plants as potent antidiabetic and wound healing agents-a review. Hygeia J.D. Med. 2011;3:11-9.

6. Soja A, Jayakumari S. A perspective review on Homalium zeylanicum Benth. Indo Am J Pharm Res. 2017;7:8092-100.

7. Tekuri MK, Krishna KL, Nidavani RB. Homalium zeylanicum Benth.: an ethnopharmacological review. World J Pharm Res. 2014;3:276-85.

8. Mahapatra AK, Pani SS, Sahoo AK. Free radical-scavenging activities of Homalium species-An endangered medicinal plant of Eastern Ghats of India. Nat Prod Res. 2015;29(22):2112-6. doi: 10.1080/14786419.2014.987142, PMID 25490920.

9. Rajesh N, Prasad SV, Nabi SK, Swapna S, Konda PY, Ali MS, et al. In vitro and in vivo studies on the antidiabetic activity of stem bark of Homalium zeylanicum in STZ induced diabetic rats. Asian J. Biochem. Pharm Res. 2014;4:76-90

10. Swathi P, Saritha C, Puligilla S. Evaluation of anti-diabetic, antidyslipidemic and hepatoprotective activity of Homalium zeylanicum in alloxan induced diabetic rats. Int J Res Dev Pharm Life Sci. 2014;3:1004-10.

11. Gnananath K, Kumar GP, Reddy KR, Kumar BN, Kumar RV. Evaluation of anthelimintic activity in the bark of Homalium zeylanium. Int Res J Pharm. 2012;3:436-7.

12. Devi VA, Mallikarjuna K. In vitro antimicrobial and antidiabetic activity of leaf extracts of Schrebera swietenioides and Homalium zeylanicum. Int J Life Sc Pharm Res. 2016:6:1-7.

13. Sahoo AK, Dash UC, Kanhar S, Mahapatra AK. In vitro biological assessment of Homalium zeylanicum and isolation of lucidenic acid A triterpenoid. Toxicol Rep. 2017;4:274-81. doi: 10.1016/j.toxrep.2017.04.004, PMID 28959649.

14. Kanhar S, Sahoo AK. Ameliorative effect of Homalium zeylanicum against carbon tetrachloride-induced oxidative stress and liver injury in rats. Biomed Pharmacother. 2019;111:305-14. doi: 10.1016/j.biopha.2018.12.045, PMID 30590318

15. Swain SK, Dash UC, Kanhar S, Sahoo AK. Ameliorative effects of Hydrolea zeylanica in streptozotocin-induced oxidative stress and metabolic changes in diabetic rats. J Ethnopharmacol. 2020;247:1-13.

16. El Kabbaoui M, Chda A, El-Akhal J, Azdad O, Mejrhit N, Aarab L, Bencheikh R,
Tazi A. Acute and sub-chronic toxicity studies of the aqueous extract from leaves of Cistus ladaniferus L. in mice and rats. J Ethnopharmacol. 2017;209:147-56. doi: 10.1016/j.jep.2017.07.029, PMID 28750941.

17. Nayak SS, Jain R, Sahoo AK. Hepatoprotective activity of Glycosmis pentaphylla against paracetamol-induced hepatotoxicity in Swiss albino mice. Pharm Biol. 2011;49(2):111-7. doi: 10.3109/13880209.2010.501084, PMID 20942640

18. Mahmud ZA, Bachar SC, Qais N. Antioxidant and Hepatoprotective Activities of Ethanolic Extracts of Leaves of Premna esculenta Roxb. against Carbon Tetrachloride-Induced Liver Damage in Rats. J Young Pharm. 2012;4(4):228-34. doi: 10.4103/0975-1483.104366, PMID 23493235

19. Aebi H. Catalase. Methods Enzym Anal. 1974;2:674-84.

20. Ellman GL. Tissue sulfhydryl groups. Arch Biochem Biophys. 1959;82(1):70-7. doi: 10.1016/0003-9861(59)90090-6, PMID 13650640.

21. Rahman MM, Islam Md, Biswas $M$, Alam AHMK. In vitro antioxidant and free radical scavenging activity of different parts of Tabebuia pallida growing in Bangladesh. BMC Res Notes. 2015;8:1-9.

22. Huyut Z, Beydemir S, Gülçin I. Antioxidant and Antiradical Properties of Selected Flavonoids and Phenolic Compounds. Biochem Res Int. 2017:2017:7616791. doi: 10.1155/2017/7616791. PMID 29158919.

23. Boora F, Chirisa E, Mukanganyama S. Evaluation of nitrite radical scavenging properties of selected Zimbabwean plant extracts and their phytoconstituents. Journal of Food Processing. 2014;2014:1-7. doi: 10.1155/2014/918018.

24. Recknagel RO, Glende Jr EA, Dolak JA, Waller RL. Mechanisms of carbon tetrachloride toxicity. Pharmacol Ther. 1989:43(1):139-54. doi: 10.1016/01637258(89)90050-8, PMID 2675128.

25. Drotman RB, Lawhorn GT. Serum enzymes as indicators of chemically induced liver damage. Drug Chem Toxicol. 1978;1(2):163-71. doi: 10.3109/01480547809034433, PMID 755666

26. Jang S, Hossain MA, Lee JS, Reza MA, Lee S, Kang JW, et al. Hepatoprotective effects of Ilex paraguariensis St. Hilaire (Yerb mate) extract in rats. Indian J Exp Biol. 2018;17:707-15.

27. Clawson GA. Mechanisms of carbon tetrachloride hepatotoxicity. Pathol Immunopathol Res. 1989;8(2):104-12. doi: 10.1159/000157141, PMID 2662164

28. Kuriakose GC, Kurup MG. Antioxidant and hepatoprotective activity of Aphanizomenon flos-aquae Linn against paracetamol intoxication in rats. Indian J Exp Biol. 2010;48(11):1123-30. PMID 21117453.

29. Singh B, Saxena AK, Chandan BK, Anand KK, Suri OP, Suri KA, et al. Hepatoprotective activity of verbenalin on experimental liver damage in rodents. Fitoterapia. 1998;69:135-40.

30. Parola M, Bellomo G, Robino G, Barrera G, Dianzani MU. 4-hydroxynonenal as a biological signal: molecular basis and pathophysiological implications. Antioxid Redox Signal. 1999;1(3):255-84. doi: 10.1089/ars.1999.1.3-255, PMID 11229439.

31. Greeshma P, Feba J, Zuhara FK, Janardhanan KK. Elm oyster mushroom Hypsizygus ulmarius (Bull: Fr) attenuates carbon tetrachloride induced hepatic injury in Wistar rats. Indian J Exp Biol. 2019;57:763-9.

Article History: Received: 17-05-2021; Revised: 04-06-2021; Accepted: 28-06-2021.

Cite this article: Kanhar S, Sahoo AK, Mohapatra R. Antioxidant and Hepatoprotective Activities of Hydroalcohol Extract of Homalium zeylanicum on Carbon tetrachloride Induced Liver Damage in Wistar Rats. J Young Pharm. 2021;13(3):217-22. 